\title{
Tales of Householder Ghosita, a Man Who Was a Dog Once Before:
}

The Udenavatthu and Parallel Stories in Northern Buddhism

\section{YAMAGUCHI Nariko}

\section{The Aim of This Paper and the Relevant Texts}

The Udenavatthu (hereinafter, UVt) is contained in the Dhammapada-ațthakath $\bar{a}$ (a commentary on the Dhammapada), and is an omnibus-style story of King Udena-a contemporary of the Buddha—the ruler of Vamsa, ${ }^{1)}$ and his attendants. It comprises six short stories arranged as follows: ${ }^{2)}$ (1) Udenassa Uppati, (2) Ghosakasetthino Uppati, (3) Sāmāvatiyā Vatthu, (4) Vāsuladattāya Vatthu, (5) Māgandiyā-Vatthu, and (6) Sāmāvatiyā Māgandiyāya ca Maraṇaparidīpaka-Udenavatthu.

The second story speaks of a householder named Ghosita, ${ }^{3)}$ a very wealthy man in the city of Kosambi and the father-in-law of King Udena. ${ }^{4)}$ The first half of this story mentions Ghosita's three previous incarnations, in which he was first a man named Kotūhalaka, then born as a dog, and then reborn as an inhabitant of the heavenly world. In this paper, I will address the story of his second incarnation, namely, the story about the time when he was born a dog.

An outline of the story is like so: there was a herdsman who worshipped a paccekabuddha (one enlightened by himself) and offered meals to the holy one every day. He had a dog, the previous being of Ghosita. The dog sometimes helped its owner in making the offerings and was very attached to the holy one.

In Northern Buddhism, there are some stories that tell us that Ghosita was a dog in his previous incarnation. They go like this: there was a wealthy householder named Samidhāna in the city of Bārānnasī. For twelve years, during which the city was suffering from famine, he was able to support a number of paccekabuddhas with meals. He had some helpful employees, such as a warehouseman, as well as an usher who called on the holy ones with his dog whenever the meals were ready. That dog is thought to be the previous incarnation of Ghosita. 
When comparing the stories in UVt and Northern Buddhism, one notices that there are some differences. Here, I examine the two most convincing examples of the distinct differences between these texts: the characters in the stories and the themes of the stories. I will focus on these points and show the sentences in each text.

Here are the texts to be compared and their abbreviation marks. Except for UVt, all belong to Northern Buddhism.

Udenavatthu (UVt)

Mūlasarvāstivādavinaya (MSV):

1. Classical Chinese version ${ }^{5)}(\mathrm{MSV}-\mathrm{C})$

2. Classical Tibetan version ${ }^{6)}(\mathrm{MSV}-\mathrm{T})$

3. Classical Mongolian version ${ }^{7)}(\mathrm{MSV}-\mathrm{M})$

Xianyujing 賢愚経 $(\mathrm{XJ}):^{\text {8) }}$

1. Classical Chinese version ${ }^{9)}(\mathrm{XJ}-\mathrm{C})$

2. Classical Tibetan version ${ }^{10)}(\mathrm{XJ}-\mathrm{T})$

3. Classical Mongolian version ${ }^{11)}(\mathrm{XJ}-\mathrm{M})$

Üliger-ün dalai ${ }^{12)}$ (ÜD):

1. A wood block print at the Osaka University Library ${ }^{13)}\langle\ddot{D} \mathrm{D}(\mathrm{A})\rangle$

2. A hand written copy at the Tokyo University of Foreign Studies Library ${ }^{14)}\langle\ddot{D} D$ (B) $\rangle$

3. A wood block print at the Osaka University Library ${ }^{15)}\langle\ddot{\mathrm{U} D}(\mathrm{C})\rangle$

\section{Comparison of the Topics in Each Text}

UVt tells us that the almsgiver was a herdsman, who had a dog, and that the receiver of these alms was a paccekabuddha. There are no other characters in this story.

gopālako pi nibaddham dve vāre paccekabuddhassa upatțhānam yāti, . . sunako pi tena saddhim gacchati. [171.18-23]

The dog was very attached to the holy one. One day, it was shocked by its parting from the holy one and barked until its heart broke, and it died. After that, the dog was reborn into a heavenly world (Tâvatimsa), and then was reborn again as a boy in Kosambi city - this is the birth of Ghosita.

sunakhassa tạ̣ ākāsena gacchantaṃ disvā hunkkaritvā . . k kālaṃ katvā tāvatiṃsa-bhavane 
nibbatto accharāsahassa-parivuto mahāsampattim anubhoti. [172.22-173.8]

The texts of MSV tell of a householder, named Samdhāna, who offered meals to a thousand paccekabuddhas, and tell us that he had good employees. One of them was the dog's owner, an usher, who called the holy ones whenever the meals were ready. (I will show only the sentences in MSV-C, for want of space. The sentences in MSV-T and MSV-M would be shown if they had any variation.)

有一長者. 名日善合 (Samdhāna). ${ }^{16)}$ 処分一人為掌庫者常出賜物. 於日日中以上妙飲食 供養一千独覚聖者其営食人毎日恒将一狗往白時至…… [883c7-10]

Furthermore, these texts also mention the following incarnations of the characters in the story: Samdhāna became the Buddha, the warehouseman became householder Anāthapiṇada, the usher became King Udena, and the dog became householder Ghosita.

往時善合長者. 即我身是. 掌庫人者即給孤独是. 白時至者即烏陀演那王是. 狗者即妙音 是. [883c15-17]

Concerning the characters and their following incarnations, the texts of XJ and ÜD tell almost the same story as the texts of MSV, except for the following two points. First, Samdhāna is said to have also employed five hundred cooks to prepare the meal for the holy ones. ${ }^{17)}$ (Here I will also only show the sentences in $\mathrm{XJ}-\mathrm{C}$, for want of space. The sentences in $\mathrm{XJ}-\mathrm{T}, \mathrm{XJ}-\mathrm{M}$, and ÜD would be shown if they had any variation.)

於時長者．即便請之．差五百使人．供設飯食．[386c23-24]

Second, the following incarnations of the five hundred cooks were also mentionedthey were the previous incarnations of five hundred arahants, who were the Buddha's disciples.

爾時五百作食之人. 今此五百阿羅漢是也. [387a21-22]

Furthermore, $\mathrm{XJ}-\mathrm{T}, \mathrm{XJ}-\mathrm{M}$, and the texts of ÜD do not correspond to $\mathrm{XJ}-\mathrm{C}$ with regard to the previous incarnations of the warehouseman. XJ-T, XJ-M, and the text (B) of ÜD tell us that Prince Jeta was the warehouseman, while $\mathrm{XJ}-\mathrm{C}$ tells us that Anāthapindada was the warehouseman. 
[XJ-T] bang mdzod srung ba'i [sic: ba] ${ }^{18)}$ de ni / rgyal bu rgyal byed yin no // [P 252b4]

$[\mathrm{XJ}-\mathrm{M}]$ tere čay tere ulus [sic: učir] ${ }^{19)}$-taki sang qatayalayči tere kümün edüge či $^{20)}$ buyu. [355b22-23]

[ÜD (B)] tere učir-taki sang qatayalayči tere kümün edüge či buyu. [208a7-8]

On the other hand, texts $(A)$ and $(C)$ of ÜD say that Udena was the warehouseman.

[ÜD (A), (C)] tere čay tere učir-taki sang qatayalayči tere kümün edüge udiyan-a či buyu. [(A) $162 \mathrm{a} 20-21$, (C) 190a8-10]

It has already been pointed out that XJ-T-namely, the extant Tibetan version of XJ -was translated from the old Chinese text, which must be some text other than the extant old Chinese version, XJ-C. ${ }^{21)}$ The facts shown above support such an opinion. Furthermore, I found that XJ-M is probably based on XJ-T and that $\mathrm{UD}$ (B) is very similar to XJ-M, while ÜD (A) and (C) are not.

\section{Conclusion}

The characters in each text and their previous and following incarnations are summarized in the following table. The mark "-" means that there is no corresponding description. The words in the brackets "[ ]" are those in text (B) of ÜD.

\begin{tabular}{|c|c|c|c|c|c|}
\hline & UVt & $\begin{array}{c}\text { MSV } \\
\text { (MSV-C, MSV-T, MSV-M) }\end{array}$ & $\begin{array}{c}\text { XJ } \\
(\mathrm{XJ}-\mathrm{C})\end{array}$ & $\begin{array}{c}\text { XJ } \\
(\mathrm{XJ}-\mathrm{T}, \mathrm{XJ}-\mathrm{M})\end{array}$ & ÜD \\
\hline $\begin{array}{c}\text { Almsgiver } \\
\text { (Saṃdhāna) }\end{array}$ & $-22)$ & Buddha & Buddha & Buddha & Buddha \\
\hline Warehouseman & - & Anāthapiṇdada & Anāthapiṇdada & Jeta & Udena [Jeta] \\
\hline Usher & - & Udena & Udena & Udena & Jeta [Udena] \\
\hline Dog & Ghosita & Ghosita & Ghosita & Ghosita & Ghosita \\
\hline 500 cooks & - & - & 500 arahants & 500 arahants & 500 arahants \\
\hline
\end{tabular}

Through the comparison of these texts, we can conclude the following. The stories of Ghosita's previous being in UVt and the Northern Buddhist texts have two common points: (1) Ghosita was a dog in his previous existence, and (2) its owner offered meals a holy one or holy people. However, the characters in these stories and the themes of these stories are completely different. UVt tells the story of a herdsman who had a dog and offered meals to the paccekabuddha. With regard to a previous incarnation, it only 
mentions that of Ghosita. On the other hand, in the Northern Buddhist texts, there are many more characters: a householder, named Sampdhāna and his employees, such as a warehouseman and an usher with his dog.

Furthermore, they not only mention the previous incarnation of Ghosita, but also those of the Buddha, King Udena, Prince Jeta, and so forth. We can therefore regard these stories as the Jātaka.

As seen above, the stories in UVt and in the Northern Buddhist texts might share a common source because they have several points of similarity. However, it cannot be argued that they have had a direct influence on each other. The texts of Northern Buddhism do, though, show interesting similarities and variations-they might be related to each other to some degree. Furthermore, the texts of ÜD seem to have been the product of some confusion during the making of the text.

For future research, I propose the following points: (1) comparing other stories in UVt with their parallel texts from Northern Buddhist texts to make clear the transition of the tales, and (2) a comparison and analysis of the stories among the texts of XJ, including the texts of ÜD.

\section{Notes}

1) It was one of the Solasamahäjanapada (the Sixteen Great Kingdoms) and was between Kosala and Magadha. It is called Vatsa in Sanskrit. The capital city was Kosambì. See Sattaka-nipāta, Ațthaka-nipāta, and Navaka-nipāta, ed. E. Hardy, The Angguttara Nikāya, pt. 4 (London: Pali Text Society, 1958), 252. See also Law 1932, 3.

2) This list follows The Commentary on the Dhammapada, ed. H. C. Norman, vol. 1, pt. 2 (London: published for the Pali Text Society by the Oxford University Press, 1909).

3) He was called "Ghosaka" until he took over the position of householder from his foster father. After becoming the householder, he called "Ghosita" in UVt, although the title of the chapter says us "Ghosaka-setthi." I will mention him "Ghosita" in this paper.

4) Ghosita as well as his daughter, Sāmāvatī, were earnest followers of the Buddha and made donations of ārāma.

5）Genbenshuoyiqieyoubupinaiye 根本説一切有部昆奈耶, T no. 1442, vol. 23, 883c4-19.

6) 'Dul ba rnam par 'byed pa (Vinayavibhanga), P no. 1032, vol. 43, Te 139a4-140a6, D no. 3, vol. 3, Nya 148a5-149a7. I will show the description of the Beijing edition in this paper.

7) Nomuүadqaqui teyin böged ilayayči (Vinayavibhañga), MKn, no. $1134 \mathrm{CI}$ Ta 202a29-204b25.

8) It has been pointed out that some stories in XJ have some relationship with those in MSV. See Hiraoka 2005. 
9）Xianyujing 賢愚経, T no. 202, vol. 4, 386a5-387a26, 30 Santanning pin di ershijiu 散檀寧品第 二十九.

10) mDzangs blun zhes bya ba'i mdo, P no. 1008 , vol. 40 , Hu 250b2-252b6, D no. 341, vol. 27, A 246a4248b2, Khyim bdag sdumgs byed kyi le'u ste sum bcu bzhi pa'o (the 34th story). Another critical edition is also available: Takahashi 1970,416-423. However, I will mainly show the Beijing edition in this paper.

11) Šiluyun onul-tu kemegdekü sudur, MKn, no. 1103, Hi 352b11-356a7, Indügči ejen-ü үučin tabdayar [sic] jüil (the 35th story).

12) This text was translated from Tibetan version of $\mathrm{XJ}$ into Mongolian to be a separate text from the Mongolian Kanjur by Širege-tü Gü'üši, who was a high priest of the dGe lugs pa sect and flourished as a famous translator in 16th and 17th centuries. See Cao Dou 1996.

13) No. 1 (The call number is temporary because the bibliographical data has not been ready to open), 159a20-162b6, Indügči ger-ün ejen-ü döčin doluduyar [sic] jüil (although, literally, it is said the 47th story should be the 35th one), August, 1714 (Kangxi 53). Approximate size: $21.0 \mathrm{~cm} \times 57.5$ $\mathrm{cm}$. I will mainly show the description of this text in this paper.

14) G14/180/578091. 203b25-208a27, Indügči ger-ün ejen-ü үučin tabuduyar jüil (the 35th story). Dateless. Approximate size: $11.5 \mathrm{~cm} \times 47.0 \mathrm{~cm}$.

15) No. 18 (the call number is temporary because the bibliographical data has not been ready to open), 186b15-190a25, Indügči ger-ün ejen-ü döčin doluduyar [sic] jüil (this also should be the 35th story), April, 1728 (Yongzheng 6). Approximate size: $20.0 \mathrm{~cm} \times 54.0 \mathrm{~cm}$.

16) His name is also translated as Shanxu 善続 in the Old Chinese version of MSV [T no. 1442, vol. 23, 892c27]. Cf. Cowell and Neil 1970, 540; Nishimoto 1933, 295, note 14.

17） XJ-C tells that there were totally 2000 paccekabuddhas who accepted the foods (長者即請千 辟支仏. 飯食供盖. 彼残千人. 復詣其家. 亦求供盖. [386c19-20]). Incidentally, the 2000 holy men are mentioned as "drang srong" in XJ-T (P 251b8-252a2) and "arsi" in XJ-M (354b9-26). Both words mean "ascetic," not paccekabuddha.

18) bang mdzad srung ba de ni rgyal bu rgyal byed yin no // [D 248a7]

19) Cf. tere čay tere učir-taki indügči bayan gerün eǰen kekembesü edüge bi buyu. [355b20-22]

20) či literally means "you." Here, it refers to Prince Jeta, who was listening to the Buddha's teaching.

21) See Ueyama 1967, 174; Mitani 1997.

22) In the UVt, the almsgiver is a herdsman, who is anonymous. There is no mention of his following incarnation.

\section{Abbreviations}

D Tibetan Buddhist Canon: The Nyingma Edition of the sDe-dge bKa'-'gyur and bsTan-'gyur. 120 vols. Oakland, Calif.: Dharma Publishing, 1981.

MKn Mongolian Kanjur. Ed. Lokesh Chandra. 108 vols. Śatapițaka Series: Indo-Asian Literatures, nos. 101-208. New Delhi: International Academy of Indian Culture, 1973-1979. 


\section{Bibliography}

Cao Dou 曹都, ed. 1996. Zongjiao cidian 宗教詞典 (Šasin-u toli). Hohhot: Inner Mongolia Education Press.

Cowell, E. B., and Robert A. Neil, eds. 1970. The Divyāvadāna: A Collection of Early Buddhist Legends. Amsterdam: Oriental Press.

Hardy, E., ed. 1958. Sattaka-nipāta, Ațthaka-nipāta, and Navaka-nipāta. The Añguttara Nikāya, pt. 4. London: Pali Text Society.

Hiraoka Satoshi 平岡聡. 2005. “Gengukyōo kōseisuru setsuwa no kizoku buha”『賢愚経』を構成す る説話の㷌属部派. IBK 54 (1): 187-195.

Law, Bimala Churn. 1932. Geography of Early Buddhism. London: Kegan Paul, Trench, Trubner.

Mitani Mazumi 三谷真澄. 1997. “mDzangs-blun (Gengukyō) ni kansuru ichikōsatsu” mDzangs-blun （『賢愚経』）に関する一考察. IBK 45 (2): 178-182.

Nishimoto Ryūzan 西本龍山, trans. 1933. Kokuyaku issaikyō 国訳一切経: Ritsu-bu 律部 21. Tokyo: Daitō Shuppansha.

Norman, H. C., ed. 1909. The Commentary on the Dhammapada. Vol. 1, pt. 2. London: published for the Pali Text Society by Oxford University Press.

Takahashi Moritaka 高橋盛孝, ed. 1970. Gengukyō: Zōkan taiyaku 賢愚経: 蔵漢対訳. Kansai Daigaku Tōzai Gakujutsu Kenkyūjo kenkyū sōkan 関西大学東西学術研究所研究丵刊 3. Suita: Kansai Daigaku Tōzai Gakujutsu Kenkyūjo.

Ueyama Daishun 上山大峻. 1967. "Daibankoku daitoku sanzō hōshi shamon Hōjō no kenkyū (jō)" 大蕃國大德三藏法師沙門法成の研究 (上). Tōhō gakuhō 東方學報 38: 133-198.

Key words Udenavatthu, Mūlasarvāstivādavinaya, Genbenshuoyiqieyoubupinaiye, 根本説一切有部昆 奈耶, Xianyujing, 賢愚経

(Research Fellow, The Nakamura Hajime Eastern Institute) 